Determination of Phenolic Acids by HPLC and Antioxidant Capacity of Some Cultivated Mentha Species

\author{
Mahfuz ELMASTAŞ ${ }^{\wedge}$, Mehmet KEÇECI ${ }^{2}$, Nusret GENÇ³ ${ }^{3}$, Ahmet BEYATLI ${ }^{4}$, Duygu MISIRLI5 ${ }^{5}$ Isa TELCI ${ }^{6}$ \\ 1,5Department of Biochemistry, Faculty of Hamidiye Pharmacy, University of Health Sciences, Üsküdar/Istanbul, Turkey, ${ }^{2,3}$ Department of \\ Chemistry, Institute of Science, Gaziosmanpaşa University, Tokat, Turkey, ${ }^{4}$ Department of Medical and Aromatic Plants, Hamidiye Health \\ Vocational School, University of Health Sciences, Üsküdar/Istanbul, Turkey, ${ }^{6}$ Department of Field Crops, Faculty of Agriculture, Isparta \\ University of Applied Sciences, Isparta, Turkey \\ ${ }^{1}$ https://orcid.org/0000-0002-7149-7427, ${ }^{2}$ https://orcid.org/0000-0003-1665-4677, ${ }^{3} \mathrm{https}: / /$ orcid.org/0000-0003-3685-1344 \\ ${ }^{4} \mathrm{https}: / /$ orcid.org/0000-0001-5225-6217, ${ }^{5} \mathrm{https}: / / o r c i d . o r g / 0000-0002-3581-4368,{ }^{6} \mathrm{https}: / / o r c i d . o r g / 0000-0002-3651-1641$ \\ $\bowtie$ : mahfuz.elmastas@sbu.edu.tr
}

\section{ABSTRACT}

This study was designed to investigate the phenolic acid contents and antioxidant activities of 14 clones of mint species ( $M$. spicata, $M$. piperita, $M$. villoso nervata and $M$. dumetorum) that cultivated in Turkey. The phenolic acid contents were analysed using HPLC. The antioxidant activities of these Mentha species were evaluated by free radical scavenging activity $(\mathrm{DDPH} \cdot)$, cation radical scavenging activity $\left(\mathrm{ABTS}^{\cdot+}\right)$ and reducing power activity tests. Additionally, total phenolic content of mint species was determined spectrophoto metrically using Folin-Ciacelteau's reagent. Phenolic acid contents of Mentha were evaluated in two subclasses: benzoic acid and cinnamic acid derivatives. The rosmarinic acid (which is cinnamic acid derivative) was the main phenolic acid for all tested plant material changing from 5482.6 to $31982.7 \mathrm{mg} / \mathrm{kg}$ dry weight concentrations. $\mathrm{p}^{-}$ hydroxy benzoic acid (ranging from 30.5 to $236.4 \mathrm{mg} / \mathrm{kg}$ dry weight) and syringic acid (ranging from 95.4 to $375.2 \mathrm{mg} / \mathrm{kg}$ dry weight) were most abundant benzoic acids derivatives found in tested mint clones. According to DDPH $\bullet$ and ABTS $\bullet+$ test results, while $M$. villoso nervata clone (originated from Osmaniye) has higher activity, $M$. spicata clone (originated from Manisa) has lower activity among the other clones. Reducing power activity of $M$. villoso nervata clone (originated from Osmaniye) was highest and $M$. spicata clone (originated from Konya) was lowest. It has been observed that the correlation between phenolic acid derivatives and antioxidant activity varied depending on used antioxidant activity methods. These results show that best Mentha for human health in terms of both phenolic acid content and antioxidant activity are the 3 rd clone (M. spicata) and the 10th clone ( $M$. villoso nervata) genotypes.

\section{Research Article}

$\begin{array}{ll}\text { Article History } \\ \text { Received } & : 13.08 .2020 \\ \text { Accepted } & : 19.10 .2020\end{array}$

Accepted : $: 19.10 .2020$

\section{Keywords}

Mentha

Phenolic acid

Antioxidant activity

$\mathrm{DPPH}$

ABTS

\title{
Kültürü Yapılan Bazı Mentha Türlerinin HPLC ile Fenolik Asitlerin Tayini ve Antioksidan Kapasitesi Belirlenmesi
}

\section{ÖZET}

Bu çalışma, Türkiye'de yetiştirilen $M$. spicata, $M$. piperita, $M$. villoso nervata ve $M$. dumetorum türlerine ait 14 nane klonlarının fenolik asit içerikleri ve antioksidan aktivitelerini araştırmak için tasarlanmıştır. Fenolik asit içerikleri HPLC kullanılarak analiz edilmiştir. Mentha türlerinin antioksidan aktiviteleri, serbest radikal giderme aktivitesi (DDPH·), katyon radikal giderme aktivitesi $\left(\mathrm{ABTS}^{+}{ }^{+}\right)$ve indirgeme gücü aktivite testleri ile değerlendirilmiştir. Ek olarak, nane türlerinin toplam fenolik içeriği, FolinCiacelteau'nun reaktifi kullanılarak spektrofotometrik olarak belirlenmiştir. Nane türlerinin fenolik asit içerikleri benzoik ve sinamik asit türevi olmak üzere iki alt sinıfta değerlendirilmiştir. Rosmarinik asit (sinnamik asit türevi) konsantrasyonu, test edilen tüm bitki materyalleri için 5482.6'dan 31982.7 mg/kg kuru ağırlık

\section{Araştırma Makalesi}

$\begin{array}{ll}\text { Makale Tarihçesi } & \\ \text { Geliş Tarihi } & : 13.08 .2020 \\ \text { Kabul Tarihi } & : 19.10 .2020\end{array}$

\section{Anahtar Kelimeler}

Mentha

Fenolik asit

Antioksidan aktivite

DPPH

ABTS 
arasında değiş̧en ana fenolik asit olarak gözlemlenmiştir. $p$-hidroksi benzoik asit (30.5 ile $236.4 \mathrm{mg} / \mathrm{kg}$ kuru ağırlık arasında) ve şiringik asit (95.4 ile $375.2 \mathrm{mg} / \mathrm{kg}$ kuru ağırlı arasında), test edilen nane klonlarında en yüksek miktarda bulunan benzoik asit türevleridir. $\mathrm{DDPH}^{\bullet}$ ve ABTS •+ test sonuçlarına göre $M$. villoso nervata türü (Osmaniye kaynaklı klonu) daha yüksek aktiviteye sahipken, $M$. spicata türü (Manisa kaynaklı klonu) diğer klonlar arasında daha düşük aktiviteye sahip olduğu görülmüştür. $M$. villoso nervata türü (Osmaniye kaynaklı klonu) indirgeme gücü aktivitesi düşük iken en yüksek aktiviteyi $M$. spicata türü (Konya kaynaklı klonu) göstermiştir. Fenolik asit türevleri ile antioksidan aktivite arasındaki ilişkinin, kullanılan antioksidan aktivite yöntemlerine bağlı olarak değiştiği görülmüştür. Elde edilen sonuçlara göre hem fenolik asit içeriği hem de antioksidan aktivite açısından insan sağllğı için en yararlı nane türünün 3 . klon $(M$. spicata) ve 10 . klon ( $M$. villoso nervata) genotipleri olduğunu tespit edilmiştir.

To Cite : Elmastaş M, Keçeci M, Genç N, Beyatlı N, Mısırlı D, Telci İ 2021. Determination of Phenolic Acids by HPLC and Antioxidant Capacity of Some Cultivated Mentha Species. KSU J. Agric Nat 24 (3): 488-494. https://doi.org/10.18016/ksutarimdoga.vi.780019.

\section{INTRODUCTION}

Labiate (Lamiaceae) with about 170-250 genera and 3000-3500 species considered one of the plant families spread worldwide and specially on the Mediterranean coast (Heywood et al. 1978; Baytop 1983). Mint is one of the oldest cultivated members of this family. Mentha species; In addition to being used in many civilizations since ancient times, it is a kind of spice which is used widely in Ottoman and Turkish medicine and it is noticed as a plant which is used for treatment of many kinds of diseases. Nowadays, mint is used for both spices and medicinal purposes. M. spicata and $M$. piperita are among the most commonly cultivated and used mint species in the world. At Turkey $M$. dumetorum and $M$. villoso-nervata are the most cultivated species.

In terms of human health, it is important to determine the chemical content of nutrients. In recent years, consumption of foods containing functional compounds has been encouraged and became the focus of scientific studies. Literature showed that mint species contain compounds have biological activities such as antiinflammatory (Shen et al. 2011), antioxidants, antibacterial (Lin et al. 2011) and cardioprotective (Trivedi et al. 2011). Scientists believe that these activities are due to existence of phenolic compounds. Phenolic compounds are divided into flavonoids and phenolic acids. Phenolic acids are natural antioxidants that contribute to the colour, smell and taste of plants. These compounds significantly affect the stability, colour, odour, nutrient content and quality of foods (Robbins 2003). Therefore, determination the amount of phenolic acids in foods it is one of the important issues.

According to literature search we cannot find any study on the determination of the phenolic compounds in $M$. villoso nervata and $M$. dumetorum species research is therefore required on these species. Demonstrating the phenolic acid content of these two species will guide other studies about these species. This study aimed to determine the phenolic acid content of the cultivated clones belonging to $M$. villoso nervata, $M$. dumetorum, $M$. spicata and $M$. piperita species in Turkey. It's expected that determination of phenolic acid content and antioxidant activities of these species will be helpful in the availability of better-quality products in the markets.

\section{MATERIALS and METHODS:}

\section{Chemicals and reagents}

Ferric chloride $\left(\mathrm{FeCl}_{3}\right)$, 2,2-diphenyl-picrylhydrazyl (DPPH), 2,2'-Azino-bis(3-ethylbenzothiazoline-6sulfonic acid) diammonium salt (ABTS), potassium ferricyanide $\mathrm{K}_{3} \mathrm{Fe}(\mathrm{CN})_{6}$, trichloroacetic acid (TCA), potassium dihydrogen phosphate $\left(\mathrm{KH}_{2} \mathrm{PO}_{4}\right)$, sodium carbonate $\left(\mathrm{Na}_{2} \mathrm{CO}_{3}\right)$ and Folin-Ciocalteu reagent were obtained from Sigma-Aldrich (Sternheim, Germany). 6-hydroxy-2,5,7,8-tetramethyl-2-carboxylic acid (Trolox) and gallic acid were purchased from Merck (Istanbul, Turkey). All other solvents and chemicals (analytical or HPLC grade) were obtained from SigmaAldrich.

\section{Plant materials}

Mint species distributed in different regions in Turkey examples used in breeding ecology adaptation studies in Tokat was used in this study. The mint species clones (Table 1) were obtained from research fields of Department of Field Crops, Faculty of Agriculture, Tokat Gaziosmanpaşa University (Tokat, Turkey). Dry sample of each species $(5 \mathrm{~g})$ ground in liquid nitrogen using mortar and pestle. All samples were kept at 25 ${ }^{\circ} \mathrm{C}$ until extraction. 
Table 1. Species, the origin of used Mentha clones and yield extracts.

Cizelge1. Kullanılan Mentha klonlarının kökeni ve ekstre verimleri.

\begin{tabular}{lllc}
\hline Species & $\begin{array}{l}\text { Clone } \\
\text { code }\end{array}$ & Origin (city) & $\begin{array}{c}\text { Yield of } \\
\text { extracts (\%) }\end{array}$ \\
\hline & 1 & Konya & 12.00 \\
& 2 & Adryaman - 1 & 17.50 \\
& 3 & Adryaman - 2 & 23.00 \\
M. spicata & 4 & Ankara - 1 & 18.00 \\
& 5 & Ankara - 2 & 13.50 \\
& 6 & Karaman & 11.50 \\
& 7 & Elazı̆ & 10.50 \\
M. villoso-nervata & 11 & Samsun & 10.50 \\
M. piperita & 8 & Manisa & 11.50 \\
M. dumetorum & 12 & Amasya & 14.00 \\
& 13 & Antalya & 10.50 \\
& 14 & Gaziantep & 10.00 \\
& 10 & Tokat & 14.50 \\
& & & 11.00 \\
\hline
\end{tabular}

Preparation of extraction

Thirty millilitres of a methanol/dichloromethane solution (4:1) was added to $500 \mathrm{mg}$ of prepared plant materials, the mixture was vortexed slightly for $1 \mathrm{~min}$ and then sonicated for $30 \mathrm{~min}$ in ultrasonic bath then centrifuged. The remaining solid residue was $\mathrm{re}^{-}$ extracted twice using same procedure. The collected filtrates were pooled, concentrated under reduced pressure at $40^{\circ} \mathrm{C}$ by a rotary evaporator. The extracts were used for the determination of antioxidant capacity and total phenolic compounds.

\section{Determination of total phenolic content}

Folin-Ciocalteu reagent was used to determine the total phenolic constituent of extracts (Slinkard and Singleton 1977). After adding $4.5 \mathrm{~mL}$ of distilled water to $100 \mu \mathrm{l}$ of stock solution $(1 \mathrm{mg} / \mathrm{mL}), 100 \mu \mathrm{l}$ of FolinCiocalteu reagent was added. After 3 min $300 \mu l$ (1\%) $\mathrm{Na}_{2} \mathrm{CO}_{3}$ were added. The mixture vortexed then incubated for 2 hours under room conditions. The absorbance was measured at $760 \mathrm{~nm}$ in a spectrophotometer. Calibration curve was obtained through using different concentrations of gallic acid which used as standard. The results were given as phenolic compound equivalent to g gallic acid/kg dry plant.

\section{Analysis of phenolic acids}

Qualitative analysis of the phenolic acid's derivatives (Gallic acid (GA), protocatechuic acid (PA), pHydroxybenzoic acid (p-HBA), vanillic acid (VA) syringic acid (SA), caftaric acid (CTA), caffeic acid (CFA), p-coumaric acid ( $\mathrm{p}-\mathrm{CA}$ ), ferulic acid (FA), cichoric acid (CCA), rosmarinic acid (RA) and cinnamic acid (SIA)) in the samples were performed using an HPLC-DAD (Shimadzu, Japan) system coupled with an LC 20AT pump and SPDM20A model DAD detector. The mobile phases consisted of solvent A (methanol) and solvent B (1\% formic acid in deionised water) was applied to reverse phase Dionex, Acclaim Polar Advantage $120 \mathrm{~A}^{\circ}(150 \times 4.60 \mathrm{~mm}, 3 \mu \mathrm{m}) \mathrm{C} 16$ as follows: $0 \mathrm{~min}, 100 \% \mathrm{~A}$ and $0 \% \mathrm{~B} ; 10 \mathrm{~min}, 60 \% \mathrm{~A}$ and $40 \% \mathrm{~B}$; and $17.5 \mathrm{~min}, 0 \% \mathrm{~A}$ and $100 \% \mathrm{~B}$ to wash and equilibrate of the column. The flow rate was $1 \mathrm{~mL} / \mathrm{min}$, and the column temperature was set to $30^{\circ} \mathrm{C}$. Detection was performed at $280 \mathrm{~nm}$. Identification of individual phenolic acids were performed through comparing their retention times and spectra with known standards. The amounts of individual phenolic acids were calculated by using a calibration curve equation for each one of the standards. The results were expressed as milligram per kilogram of dry weight.

\section{Determination of antioxidant activity \\ Free radical scavenging activity}

The free radical scavenging activity were evaluated by (DPPH $\cdot$ ) according to the method described by Blois (Blois, 1958). Samples at different concentrations (2.5$10 \mathrm{\mu g} / \mathrm{mL}$ ) and standard solutions were taken and completed to $3 \mathrm{~mL}$ was with ethanol. Then $\mathrm{DPPH}$. solution $(1.0 \mathrm{~mL}, 0.26 \mathrm{mM})$ were added. The reaction mixture was vortexed thoroughly, left in the dark at room temperature for $30 \mathrm{~min}$ and measured at $517 \mathrm{~nm}$. The activity was calculated by the following equation

Activity $\%=\left[\left(\mathrm{Abscontrol}^{-} \mathrm{Abs}_{\text {sample }}\right) / \mathrm{Abs}_{\text {control }}\right] \mathrm{x} 100$

Where Abscontrol and Abssample are the DPPH ' radical + ethanol and $\mathrm{DPPH}^{\cdot}$ radical + samples absorbance, respectively. The inhibitory concentration $\left(\mathrm{IC}_{50}\right)$ of the samples which needed to inhibit $50 \%$ of the DPPH radicals obtained from the standard curve was compared to that of standard antioxidant (Trolox).

\section{Cation free radical scavenging activity}

2,2"-Azino-bis (3-ethylbenzthiazoline-6-sulfonic acid) $\left(\mathrm{ABTS}^{+}\right)$cation radical scavenging activity determined according to method described by Re and colleagues (Re et al., 1999). Treatment of ABTS (2.0 $\mathrm{mM}$ ) prepared in phosphate buffer $(0.1 \mathrm{M}, \mathrm{pH}$ 7.4) with potassium persulfate $\left(\mathrm{K}_{2} \mathrm{~S}_{2} \mathrm{O}_{8}\right)$ in a ratio $1: 2(2.45 \mathrm{mM})$ gave the $\mathrm{ABTS}^{\cdot+}$, which kept at dark at room temperature for $6 \mathrm{~h}$. ABTS ${ }^{\cdot+-} \mathrm{K}_{2} \mathrm{~S}_{2} \mathrm{O}_{8}$ solution $(1.0 \mathrm{~mL})$ was added to each standard and extract solution at different concentration $(2.5-10 \mu \mathrm{g} / \mathrm{mL})$. After $30 \mathrm{~min}$ of incubation, the inhibition was calculated for each concentration relative to a blank absorbance at 734 $\mathrm{nm}$. Experiments were performed in triplicate. Cation free radical scavenging activity was calculated as \% inhibition by the following equation:

Activity $\%=\left[\left(\mathrm{Abscontrol}^{-} \mathrm{Abs}_{\text {sample }}\right) / \mathrm{Abs}_{\text {control }}\right] \mathrm{x} 100$

Where Abscontrol and Abssample are the buffer + ABTS ${ }^{\cdot+-}$ $\mathrm{K}_{2} \mathrm{~S}_{2} \mathrm{O}_{8}$ solution and buffer + ABTS $^{\cdot+-} \mathrm{K}_{2} \mathrm{~S}_{2} \mathrm{O}_{8}$ solution + samples absorbance, respectively. The results were plotted against the concentration activity. The $\mathrm{IC}_{50}$ was calculated by using the slope equation. 


\section{Ferric reducing antioxidant power (FRAP)}

The reducing power of the extracts was determined by the method of Oyaizu (Oyaizu, 1986) with a slight modification (Elmastaş et al., 2006). Different concentrations $(2.5-10 \mu \mathrm{g} / \mathrm{mL})$ of the extracts were completed to $1.25 \mathrm{~mL}$ with phosphate buffer $(0.2 \mathrm{M}, \mathrm{pH}$ 6.6) and $1.25 \mathrm{~mL}$ of (1\%) potassium ferricyanide, followed by incubation for $20 \mathrm{~min}$ at $50^{\circ} \mathrm{C}$ and then received $1.25 \mathrm{~mL}$ of $(10 \%) \mathrm{TCA}$ to terminate the reaction. The solution mixed with $0.25 \mathrm{~mL}(0.1 \%) \mathrm{FeCl}_{3}$ solution and the mixture vortexed vigorously. The absorbance was measured at $700 \mathrm{~nm}$. Increased absorbance was evaluated as increased reducing power. The results were expressed in $\mu$ mol Trolox Equivalent per gram extract.

\section{Statistical analysis}

All statistical analyses were performed using the SPSS software (SPSS 15.0) program. Data are expressed as mean values and standard deviations (SD) of the triplicate results. Significant differences in groups were indicated at $\mathrm{p}<0.05$. The correlation analysis was performed by bivariate (Pearson's) correlation test at $\mathrm{p}<0.05$ significance level.

\section{RESULTS and DISCUSSION}

\section{Total phenolic content}

The highest phenolic content in the total phenolic analysis was determined in clone 9 for $M$. spicata and in clone 11 for $M$. villoso-nervata. While the highest content for M. piperita was at clone 13 .

\section{Phenolic acids}

Phenolic acid composition for the used mint species clones were determined by HPLC. Firstly, the calibration graph was drawn by using different concentrations of the standards. The phenolic acids and its amounts for each clone were determined using the calibration equation. The results were given as derivatives of benzoic acid and cinnamic acid (Table 2 and 3).

Table 2. Benzoic acid derivatives concentration in Mentha clones (mg/kg dry plant material).

Cizelge 2. Mentha klonlarındaki benzoik asit türevlerin konsantrasyonlar ( $\mathrm{mg} / \mathrm{kg}$ kuru bitki materyali).

\begin{tabular}{llllllll}
\hline Species & Clone code & GA & PA & $p$-HBA & VA & SA & Total \\
\hline & 1 & 0.0 & 9.6 & 145.8 & 67.5 & 259.6 & 482.5 \\
& 2 & 0.0 & 3.0 & 103.7 & 65.0 & 254.2 & 425.8 \\
& 3 & 0.0 & 3.0 & 183.1 & 183.1 & 315.8 & 685.0 \\
M. spicata & 4 & 0.0 & 16.4 & 174.8 & 0.0 & 247.6 & 438.8 \\
& 5 & 0.0 & 10.4 & 30.4 & 46.0 & 188.0 & 274.7 \\
& 6 & 0.0 & 15.5 & 115.4 & 0.0 & 95.4 & 226.3 \\
& 7 & 0.0 & 2.4 & 96.3 & 0.0 & 326.4 & 425.1 \\
M. villoso nervata & 8 & 85.2 & 26.1 & 30.5 & 28.2 & 232.7 & 402.7 \\
M. piperita & 9 & 48.9 & 10.7 & 70.3 & 40.7 & 207.9 & 378.4 \\
M. Dumetorum & 11 & 0.0 & 3.3 & 142.6 & 0.0 & 304.3 & 450.2 \\
\hline
\end{tabular}

Gallic acid (GA), protocatechuic acid (PA), p-Hydroxybenzoic acid (p-HBA), vanillic acid (VA) and syringic acid (SA).

Table 3. Cinnamic acid derivatives concentration in Mentha clones (mg/kg dry plant material).

Cizelge 3. Mentha klonlarındaki sinnamik asit türevlerinin konsantrasyonu ( $\mathrm{mg} / \mathrm{kg}$ kuru bitki materyali).

\begin{tabular}{|c|c|c|c|c|c|c|c|c|c|}
\hline Species & Clone code & CTA & CFA & $p-\mathrm{CA}$ & FA & $\mathrm{CCA}$ & RA & SIA & Total \\
\hline \multirow{10}{*}{ M. spicata } & 1 & 154.3 & 6.5 & 17.5 & 58.1 & 0.0 & 6213.8 & 75.4 & 6525.4 \\
\hline & 2 & 98.1 & 28.8 & 446.8 & 38.0 & 0.0 & 14309.0 & 268.9 & 15189.5 \\
\hline & 3 & 33.5 & 51.4 & 930.1 & 52.8 & 0.0 & 31982.7 & 603.7 & 33654.1 \\
\hline & 4 & 28.5 & 41.1 & 1095.3 & 58.5 & 0.0 & 15990.3 & 832.4 & 18046.0 \\
\hline & 5 & 28.3 & 3.7 & 782.2 & 25.4 & 0.0 & 12635.2 & 8.4 & 13483.0 \\
\hline & 6 & 186.7 & 9.7 & 19.4 & 71.9 & 0.0 & 9386.7 & 429.3 & 10103.5 \\
\hline & 7 & 165.0 & 17.1 & 51.4 & 57.9 & 0.0 & 10488.5 & 189.6 & 10969.3 \\
\hline & 8 & 59.1 & 1.3 & 87.1 & 27.4 & 0.0 & 9039.0 & 56.2 & 9269.9 \\
\hline & 9 & 130.8 & 3.0 & 13.9 & 34.7 & 0.0 & 7242.1 & 270.8 & 7695.2 \\
\hline & 10 & 140.8 & 9.0 & 43.0 & 47.5 & 0.0 & 16146.5 & 226.1 & 16612.8 \\
\hline \multirow{2}{*}{ M. villoso nervata } & 11 & 129.2 & 7.6 & 68.1 & 67.3 & 0.0 & 10200.9 & 520.4 & 10993.4 \\
\hline & 12 & 129.9 & 3.9 & 29.9 & 27.3 & 0.0 & 6577.1 & 19.5 & 6787.5 \\
\hline M. piperita & 13 & 281.3 & 3.8 & 12494.4 & 67.4 & 0.0 & 5482.6 & 102.7 & 18432.2 \\
\hline M. dumetorum & 14 & 87.1 & 2.8 & 6822.7 & 111.7 & 0.0 & 14474.4 & 186.9 & 21685.6 \\
\hline
\end{tabular}

Caftaric acid (CTA), caffeic acid (CFA), p-coumaric acid (p-CA), ferulic acid (FA), cichoric acid (CCA), rosmarinic acid (RA) and cinnamic acid (SIA). 
The highest benzoic acid derivatives content was determined syringic acid and lowest was observed as protocatechuic acid (Table 2). The highest cinnamic acid derivatives content was observed as rosmarinic acid in Mentha spicata clones (clone1-9) and cichoric acid was not detected in the tested Mentha species (Table 3).

\section{Antioxidant activities}

The values of free radical scavenging activity and cation free radical scavenging activity were calculated according to $\mathrm{IC}_{50}$, which is defined as the concentration of sample necessary to obtain an activity of $50 \%$. Decreased $\mathrm{IC}_{50}$ value meant higher activity. Reducing power activity was calculated as $\mu$ mol Trolox equivalent/mg extract.

\section{Free radical scavenging activity}

As shown in Table 4 free radical scavenging activities were given as $\mathrm{IC}_{50}$, except clones $1(22.14 \mu \mathrm{g} / \mathrm{mL}), 9$ $(33.20 \mu \mathrm{g} / \mathrm{mL})$, and $12(21.10 \mu \mathrm{g} / \mathrm{mL})$, the other clones have high activity specially clones $7(9,13 \mu \mathrm{g} / \mathrm{mL})$, clone
$10(8.94 \mu \mathrm{g} / \mathrm{mL})$, and clone11 (8.15 $\mu \mathrm{g} / \mathrm{mL})$ which showed DPPH free radical scavenging activity close to the standard material, Trolox $(6.66 \mu \mathrm{g} / \mathrm{mL})$.

In the study of Kanatt and colleagues on $M$. spicata, the $\mathrm{IC}_{50}$ value of free radical scavenging activity was found to be $25.8 \mu \mathrm{g} / \mathrm{mL}$. When we compare with $M$. spicata clones (clones 1-9) in the study, if we exclude the clone 9, other clones free radical scavenging activities were higher more than results found by Kanatt and colleagues (Kanatt et al., 2007).

Free radical scavenging activity of $M$. dumetorum extract determined as $1.6 \mathrm{mg} / \mathrm{mL}$ (Ayar-Kayali et al., 2009). Obtained results for $M$. dumetorum (clone 14) $(16,99 \mu \mathrm{g} / \mathrm{mL})$ showed that free radical scavenging activity was higher than the previous study (Table 4).

\section{Cation free radical scavenging activity}

All clones have high ABTS + free radical scavenging activity, clones $7(3.29 \mu \mathrm{g} / \mathrm{mL})$ and $11(3.03 \mu \mathrm{g} / \mathrm{mL})$ show better activity than Trolox $(3.14 \mu \mathrm{g} / \mathrm{mL})$ (Table 4). The lowest activity was observed in clone $9(6.07$ $\mu \mathrm{g} / \mathrm{mL}$ ).

Table 4. Antioxidant activities and total phenolic compound content in mint clones

Cizelge4. Nane klonlarının antioksidan aktiviteleri ve toplam fenolik bileşik içerikleri

\begin{tabular}{|c|c|c|c|c|c|}
\hline Species & $\begin{array}{l}\text { Clone } \\
\text { code }\end{array}$ & $\begin{array}{l}\text { DPPH } \\
\left(\mathrm{IC}_{50} \mu \mathrm{g} / \mathrm{mL}\right)\end{array}$ & $\begin{array}{l}\text { ABTS } \\
\left(\mathrm{IC}_{50} \mu \mathrm{g} / \mathrm{mL}\right)\end{array}$ & $\begin{array}{l}\text { FRAP } \\
\text { (umol TE/mg Extract) }\end{array}$ & $\begin{array}{l}\text { Total Phenolic } \\
\text { Compound } \\
\text { (g GAE/kg DW) }\end{array}$ \\
\hline \multirow{9}{*}{ M. spicata } & 1 & $22.14 \pm 0.24$ & $4.92 \pm 0.10$ & $3.21 \pm 0.18$ & $9.01 \pm 0.08$ \\
\hline & 2 & $13.06 \pm 0.24$ & $4.23 \pm 0.11$ & $5.14 \pm 0.18$ & $7.87 \pm 0.07$ \\
\hline & 3 & $11.25 \pm 0.25$ & $3.62 \pm 0.12$ & $5.42 \pm 0.19$ & $8.10 \pm 0.08$ \\
\hline & 4 & $14.03 \pm 0.21$ & $3.75 \pm 0.19$ & $4.75 \pm 0.18$ & $7.72 \pm 0.05$ \\
\hline & 5 & $18.22 \pm 0.20$ & $4.76 \pm 0.16$ & $4.51 \pm 0.19$ & $8.23 \pm 0.05$ \\
\hline & 6 & $13.23 \pm 0.25$ & $3.93 \pm 0.12$ & $3.93 \pm 0.18$ & $9.02 \pm 0.09$ \\
\hline & 7 & $9.13 \pm 0.21$ & $3.29 \pm 0.09$ & $6.72 \pm 0.19$ & $7.89 \pm 0.21$ \\
\hline & 8 & $14.30 \pm 0.26$ & $4.56 \pm 0.12$ & $5.93 \pm 0.19$ & $9.56 \pm 0.12$ \\
\hline & 9 & $33.20 \pm 0.23$ & $6.07 \pm 0.11$ & $3.84 \pm 0.19$ & $10.91 \pm 0.09$ \\
\hline \multirow{3}{*}{$\begin{array}{l}\text { M. villoso } \\
\text { nervata }\end{array}$} & 10 & $8.94 \pm 0.26$ & $3.79 \pm 0.12$ & $6.37 \pm 0.18$ & $6.21 \pm 0.15$ \\
\hline & 11 & $8.15 \pm 0.28$ & $3.03 \pm 0.14$ & $7.18 \pm 0.18$ & $10.83 \pm 0.11$ \\
\hline & 12 & $21.10 \pm 0.26$ & $4.41 \pm 0.16$ & $3.96 \pm 0.19$ & $7.92 \pm 0.09$ \\
\hline M. piperita & 13 & $13.11 \pm 0.24$ & $3.49 \pm 0.11$ & $5.19 \pm 0.18$ & $5.60 \pm 0.14$ \\
\hline \multirow[t]{2}{*}{ M. Dumetorum } & 14 & $15.80 \pm 0.27$ & $4.57 \pm 0.13$ & $5.09 \pm 0.18$ & $7.51 \pm 0.10$ \\
\hline & Trolox & $6.66 \pm 0.23$ & $3.14 \pm 0.10$ & & \\
\hline
\end{tabular}

\section{Reducing power activity}

As shown in Table 4, clone 7 (6.72 $\mu \mathrm{mol} \mathrm{TE} / \mathrm{mg}$ Extract), clone 10 (6.37 $\mu \mathrm{mol} \mathrm{TE} / \mathrm{mg}$ Extract), and clone 11 (7.18 $\mathrm{mmol} \mathrm{TE} / \mathrm{mg}$ Extract) are higher than other clones. The lowest activity is observed in clone 1 (3.21 $\mathrm{\mu mol} \mathrm{TE} / \mathrm{mg}$ Extract).

\section{Correlation and cluster analysis}

Correlation analysis was used to explore the relationship between the benzoic acid and cinnamic acid derivatives of mint species and the antioxidant variables (Table 5). Among benzoic acid derivatives we found medium positive correlation for GA with DPPH and ABTS tests, PA with ABTS test and SA with reducing power activity. The correlation was weak positive for DPPH with PA and weak negative for DPPH and ABTS with $p$-HBA, VA and SA. Also, for PA with reducing power activity it was weak negative. For the remaining values there was no correlation (Table 5).

For the cinnamic acid derivatives we determined medium negative correlation for CFA with DPPH and ABTS tests, RA with DPPH and FA and SIA with ABTS. Weak negative correlation founded for DPPH 
with $p$-CA, FA and SIA; for ABTS with CTA, $p$-CA and RA. The correlation of FA, RA and SIA with reducing power activity were weak positive. While the remaining values have no correlation (Table 5). For the correlation between phenolic contents and antioxidant capacity among the different methods some earlier studies showed a strong positive correlation (Katsube et al. 2004; Djeridane et al. 2006), other studies showed poor correlation (Wong et al., 2006). Antioxidant activity is not only linked with the materials of experiments but also with the used solvents, concentrations and time of reaction (Jayaprakasha et al., 2001). All factors above may lead to the correlation differences between this study and others.

Table 5. Correlation between benzoic acid derivatives and cinnamic acid derivatives with antioxidant activities. Cizelge 5. Benzoik asit türevleri ve sinnamik asit türevlerinin antioksidan aktivite ile korelasyonları.

\begin{tabular}{lllll}
\hline \multirow{2}{*}{ Correlation } & & \multicolumn{3}{l}{ Antioxidant Activities } \\
\cline { 2 - 5 } & DPPH & ABTS $^{*+}$ & Reducing Power Activity \\
\hline \multirow{3}{*}{ Benzoic acid } & GA & 0.4541 & 0.4775 & 0.0924 \\
derivatives & PA & 0.2603 & 0.3702 & 0.2877 \\
& $p$-HBA & 0.1315 & 0.1538 & 0.0981 \\
& VA & 0.1048 & 0.1454 & 0.0090 \\
& SA & 0.2902 & 0.2354 & 0.4740 \\
\hline \multirow{2}{*}{ Cinnamic acid } & CTA & 0.0321 & 0.1960 & 0.0191 \\
derivatives & CFA & 0.3434 & 0.3458 & 0.0928 \\
& $p$-CA & 0.1161 & 0.1695 & 0.0155 \\
& FA & 0.2850 & 0.3125 & 0.1192 \\
& CCA & 0.0000 & 0.0000 & 0.0000 \\
& RA & 0.3905 & 0.2924 & 0.2473 \\
\hline
\end{tabular}

Gallic acid (GA), protocatechuic acid (PA), p-Hydroxybenzoic acid (p-HBA), vanillic acid (VA) and syringic acid (SA). Caftaric acid (CTA), caffeic acid (CFA), p-coumaric acid (p-CA), ferulic acid (FA), cichoric acid (CCA), rosmarinic acid (RA) and cinnamic acid (SIA).

In the clustering analysis (Table 5), except one clone, the most abundant phenolic acid was found to be rosmarinic acid. However, the other phenolic acids were effective in grouping because the quantitative change of this compound. The clones were divided into two main groups. One of this main groups is the 3rd clone. In this clone, the amount of rosmarinic acid was quite high (31982.70 mg/kg dry plant), which was different from other clones. The second main group divided to two sub-groups. In clone 13, the difference than other clones were the high level of $p$-coumaric acid (12494.4 mg / kg dry plant). The remaining clones were further divided into two groups from these clones 14 which have high ratio of rosmarinic acid as well as $\mathrm{p}$-coumaric acid. The other sub-groups are determined by the change in the amount of rosmarinic acid. For example, in clones 1, 12 and 9 of the same group, rosmarinic acid ranges from $6213.80-7242.10 \mathrm{mg} / \mathrm{kg}$ dry plants, whereas clones $6,8,7$ and 11 which are in different group the amount ranged between 1284.40$9039.00 \mathrm{mg} / \mathrm{kg}$ dry plant. Similarly, clones 4, 10, 2 and 5 with close rosmarinic acid values $(14770.25 \mathrm{mg} / \mathrm{kg}$ dry plant) were in the same group. Hence, quantitative values of rosmarinic acid, was found to be more effective in grouping rather than the phenolic acids.

Mint is a widely used plant among the people. Therefore, the determination of the change in the amount of phenolic acids between the mint species and their clones, revealing commercially useful clones and providing scientific literatures which shedding light on future studies are so important issues. In this study, the best mint for human health in terms of both phenolic acid and antioxidant content are the clone 7 (M. spicata), clone 10 (M. villoso nervata) and clone11 (M. villoso nervata) genotypes. In terms of human health, producers need to cultivate these mint types and recommend them to consumers.

\section{Author's Contributions}

The contribution of the authors is equal.

\section{Statement of Conflict of Interest}

Authors have declared no conflict of interest.

\section{ACKNOWLEDGEMENT:}

The authors thank to Gaziosmanpasa University for its contributions and to Prof. Dr. Ahmet Ilcim for the identification of plant species. The authors also thank to Prof. Dr. Ramazan Erenler (Head of Erenler Group) and Due to their scientific and laboratory facility contributions to BALAB staff.

\section{REFERENCES}

Ayar Kayali H, Raziye Ozturk U, Mahmure N, Leman T 2009. Antioxidant Activities of Endemic Sideritis Leptoclada and Mentha Dumetorum Aqueous Extracts Used in Turkey Folk Medicine. Journal of 
Food Processing and Preservation 33(3):285-295.

Baytop A 1983. Farmasötik Botanik, 4. İlaveli Baskı. Dilek Matbaası, İstanbul

Blois MS 1958. Antioxidant Determinations by the Use of a Stable Free Radical. Nature 181(4617):11991200.

Djeridane A, Yousfi B, Nadjemi D, Boutassouna SP, Vidal N 2006. Antioxidant Activity of Some Algerian Medicinal Plants Extracts Containing Phenolic Compounds. Food Chemistry 97(4):654660.

Elmastaş M, Gülçin İ, Beydemir Ş, Küfrevioğlu Öİ, Aboul-Enein HY 2006. A Study on the in Vitro Antioxidant Activity of Juniper (Juniperus Communis L.) Fruit Extracts. Analytical Letters 39(1):47-65.

Heywood V, Hilton D, Moore M, Dunkley J, King C 1978. Flowering Plants of the World. Vol. 336. Oxford University Press Oxford.

Jayaprakasha GK, Singh RP, Sakariah KK 2001. Antioxidant Activity of Grape Seed (Vitis Vinifera) Extracts on Peroxidation Models in Vitro. Food Chemistry 73(3):285-290.

Kanatt SR, Chander R, Sharma A 2007. Antioxidant Potential of Mint (Mentha Spicata L.) in RadiationProcessed Lamb Meat. Food Chemistry 100(2):451458.

Katsube T, Tabata H, Ohta Y, Yamasaki Y, Anuurad E, Shiwaku K, Yamane Y 2004. Screening for Antioxidant Activity in Edible Plant Products: Comparison of Low-Density Lipoprotein Oxidation Assay, DPPH Radical Scavenging Assay, and FolinCiocalteu Assay. Journal of Agricultural and Food Chemistry 52(8):2391-2396.

Lin L, Dong Y, Yang B, Zhao M 2011. Chemical
Constituents and Biological Activity of Chinese Medicinal Herb 'Xihuangcao. Combinatorial Chemistry \& High Throughput Screening 14(8):720-729.

Oyaizu M 1986. Studies on Products of Browning Reactions: Antioxidative Activities of Products of Browning Reaction Prepared from Glucosamine. Japanese Journal of Nutrition 44: 307-315.

Re R, Pellegrini N, Proteggente A, Pannala A, Yang M, Rice-Evans C 1999. Antioxidant Activity Applying an Improved ABTS Radical Cation Decolorization Assay. Free Radical Biology and Medicine 26(910):1231-1237.

Robbins RJ 2003. Phenolic Acids in Foods: An Overview of Analytical Methodology. Journal of Agricultural and Food Chemistry 51(10):28662887.

Shen D, Pan MH, Wu QL, Park CH, Juliani HR, Ho CT, Simon JE 2011. A Rapid LC/MS/MS Method for the Analysis of Nonvolatile Antiinflammatory Agents from Mentha Spp. Journal of Food Science 76(6):C900-C908.

Slinkard K, Singleton VL 1977. Total Phenol Analysis: Automation and Comparison with Manual Methods. American Journal of Enology and Viticulture 28(1):49-55.

Trivedi PP, Kushwaha S, Tripathi DN, Jena GB 2011. Cardioprotective Effects of Hesperetin against Doxorubicin-Induced Oxidative Stress and DNA Damage in Rat. Cardiovascular Toxicology 11(3):215-225.

Wong SP, Leong LP, Koh JHW 2006. Antioxidant Activities of Aqueous Extracts of Selected Plants. Food Chemistry 99(4):775-783. 